\title{
Contrasting thermal structure, melt depletion and metasomatism of mantle lithosphere beneath two Proterozoic terranes west of the Kaapvaal Craton, southern Africa
}

\author{
Ellwin T. Shiimi ${ }^{1}$ \& Philip E. Janney ${ }^{1}$ \\ ${ }^{l}$ Department of Geological Sciences, University of Cape Town, Rondebosch, South Africa
}

\section{Introduction}

The Archean Kaapvaal Craton of southern Africa is bounded to the west and south by two Proterozoic terranes (Fig. 1): the Rehoboth Province (RP) and Namaqua-Natal Province (NNP). Mineral major and trace element data were obtained for garnet bearing peridotite xenoliths exhumed from four Late Cretaceous Group 1 kimberlites (71-83 Ma; Davis et al., 1976; Davies et al., 2001; Griffin et al., 2014) located near the RP-NNP border. These are Rietfontein and Louwrensia (one of the Gibeon cluster kimberlite pipes) in the southern RP, and Hoedkop and Pofadder in the northwestern NNP (Figure 1). Forty-four peridotite xenoliths were investigated from these four localities in order to compare the thermal and metasomatic characteristics of the mantle lithosphere beneath these terranes with each other and with the Kaapvaal Craton. Major element mineral data have been published for peridotites from the Louwrensia and Hoedkop localities (Boyd et al., 2004; Janney et al., 2010), but not for those from Rietfontein or Pofadder. New clinopyroxene and garnet trace element data were obtained for all samples by laser ablation ICP-MS at UCT. For both major and trace element data, there were no significant compositional differences observed between cores and rims of the grains analysed.
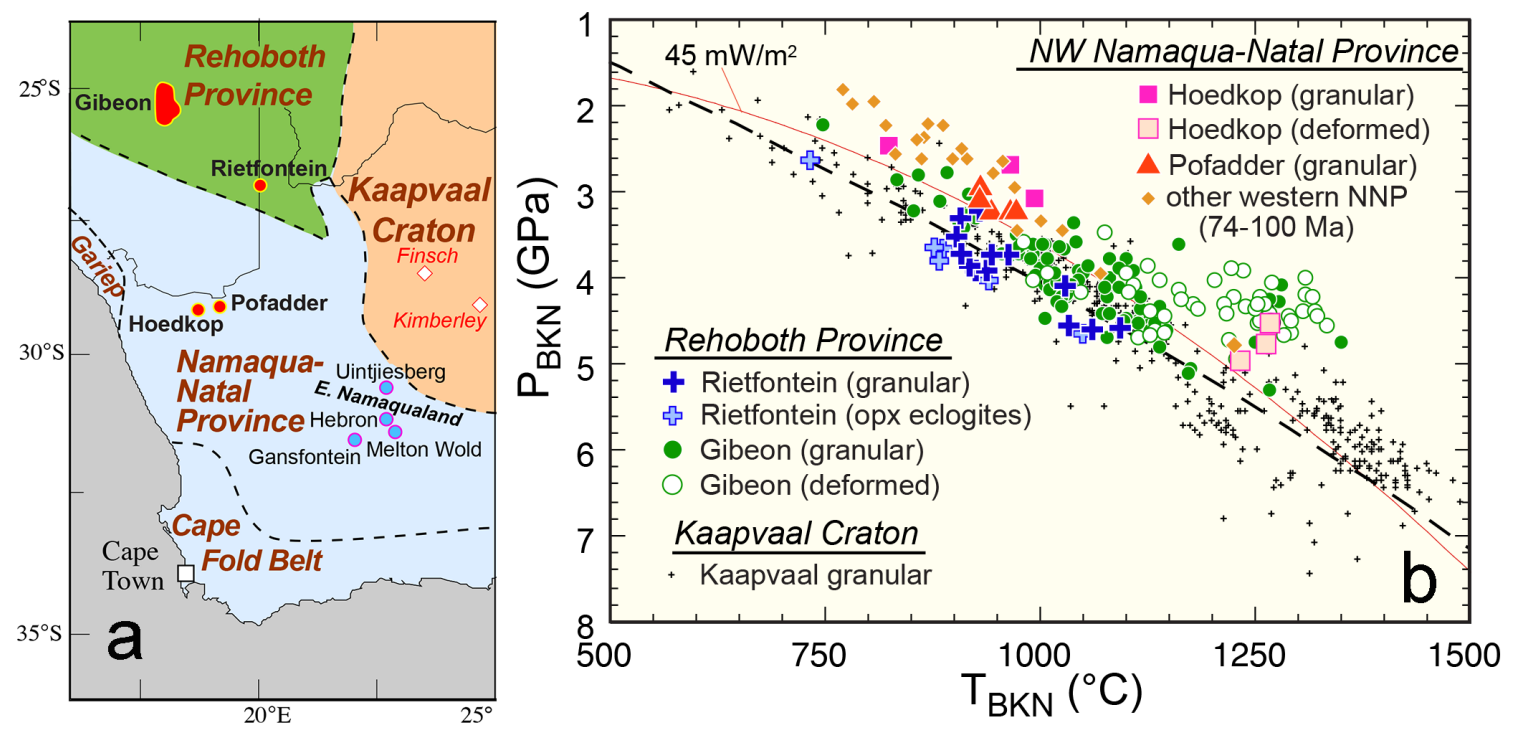

Figure 1. (a) Location map of the RP, western NNP and western Kaapvaal Craton in southern Africa, showing the xenolith localities investigated in this study (red). Also shown are the locations of other off-craton xenolith localities in the western NNP. (b) $\mathrm{T}_{\mathrm{BKN}}-\mathrm{P}_{\mathrm{BKN}}$ plot for garnet peridotites from the RP, western NNP and Kaapvaal craton. The dashed curve is the "Kalahari geotherm" of Rudnick \& Nyblade (1999) and the thin red curve is the $45 \mathrm{mWm}^{-2}$ geotherm of Pollack and Chapman (1977), which effectively separates the bulk of the granular RP peridotites from the higher temperature peridotites from the western NNP.

\section{Thermobarometry results and discussion}

Based on the combined $\mathrm{T}_{\mathrm{BKN}}-\mathrm{P}_{\mathrm{BKN}}$ thermobarometer of Brey and Köhler (1990), the majority of xenoliths from the RP display pressures and temperatures that overlap with granular peridotites from the Kaapvaal craton. Like cratonic peridotites, these granular off-craton peridotites lie between the 40 and $45 \mathrm{mWm}^{-2}$ conductive geotherms of Pollack and Chapman (1977) and most fall along the Kalahari 
paleogeotherm of Rudnick and Nyblade (1999). This appears to be a regional feature of the RP, and is consistent with values for opx-bearing eclogites from the Rietfontein kimberlite pipe (Appleyard et al., 2007) and other peridotites from Gibeon kimberlite field (Mitchell, 1984; Franz et al., 1996a; Boyd et al., 2004). In contrast, granular peridotites from Pofadder and Hoedkop record higher temperatures (by $50-100^{\circ} \mathrm{C}$ ) for any given pressure and lie between the 45 and $50 \mathrm{mWm}^{-2}$ geotherms, similar to other garnet peridotites from late Cretaceous kimberlties in the western NNP (Janney et al., 2010). However, these higher temperatures in the NNP do not appear to be a long-term feature of the regional lithosphere, as data for garnet peridotites from an older kimberlite also in the western NNP, Melton Wold ( $\approx 150 \mathrm{Ma}$; Griffin et al., 2014), also coincide with the Kaapvaal/Kalahari geotherm. This suggests that the western NNP has been affected by a regional thermal disturbance that did not affect xenoliths from the RP prior to their entrainment (Bell et al., 2003).

The similarities in geothermal gradients between the RP and the western NNP (prior to $100 \mathrm{Ma}$, as indicated by Melton Wold) and the Kaapvaal Craton suggests that at one time they may have had a similar thickness (Bell et al., 2003; Boyd et al., 2004; Janney et al., 2010). Seismological constraints currently indicate that the RP and western NNP are 30 to $50 \mathrm{~km}$ thinner than typical Kaapvaal craton lithosphere (e.g., Chevrot \& Zhao, 2007). Significant lithospheric thinning, contemporaneous with or following late Cretaceous kimberlite magmatism, thus appears to have occurred, and would most likely have occurred via melt-lithosphere interaction/thermal erosion due to the lack of evidence for regional extension (e.g., Boyd et al., 2004; Kobussen et al., 2008; 2009; Janney et al., 2010).

\section{Geochemistry results}

All garnets studied from the 4 localities have relatively low $\mathrm{Cr}_{2} \mathrm{O}_{3} / \mathrm{Al}_{2} \mathrm{O}_{3}$ values, in addition to being calcic, and fall in the lherzolitic (G9) compositional field on plots of $\mathrm{CaO} v \mathrm{vs} \mathrm{Cr}_{2} \mathrm{O}_{3}$ implying a lower degree of melt extraction than typical garnet from cratonic peridotites. There is a large degree of overlap in major element composition between data for the garnet studied and that for peridotitic garnet from Kimberley, although a significant population from Kimberley are also subcalcic. Assuming the concentration of HREE and $\mathrm{Y}$ in garnet to be unmodified subsequent to the last partial melting allows further assessment of melt depletion. Garnets from Rietfontein (RP) peridotites are characterised by "normal" REE patterns with high values and flat patterns in the MREE-HREE and strong depletions in the LREE, as well as relatively high high average Y contents of $21 \pm 12 \mathrm{ppm}$. The majority of garnets from Louwrensia have similar garnets with normal REE patterns and high average $\mathrm{Y}$ content of $22 \pm 10 \mathrm{ppm}$, but a minority have sinusoidal REE patterns (with relatively low $\mathrm{Tb}$ to $\mathrm{Er}$ abundances) and low Y contents of $10 \pm 2 \mathrm{ppm}$, similar to typical Kaapvaal peridotite garnets with $\mathrm{Y}$ contents of 7-10 ppm. These latter values suggest unusually high degrees of melting for off-craton settings, but peridotite garnets with similar compositions have also been described from other Gibeon kimberlite localities (Luchs et al., 2013). Garnets from Hoedkop (NNP) have normal REE patterns but with slightly lower than typical MREE-HREE contents as well as low average Y contents of $11 \pm 4$ ppm. Garnets from Pofadder (NNP) are unusual in having relatively linear, positively sloping normal REE patterns, show moderate chondrite normalised HREE contents along with average $Y$ content of $15 \pm 3$ ppm suggesting relatively mild degrees of melting.

Clinopyroxenes from Rietfontein, Louwrensia and Hoedkop all have similar LREE-enriched, HREE depleted patterns with maximum enrichments in Ce, Pr or Nd. Pofadder cpx is distinct in having unusual linear REE patterns with maximum enrichments in La and strong depletions in the heaviest REE, as well as unusually strong depletions in the HFSE Zr, Hf and Ti.

\section{Metasomatism}

Minerals from the RP and western NNP peridotites have incompatible element enrichments indicative of significant metasomatism. Peridotites from the RP preserve evidence for moderate metasomatic enrichment in the highly incompatible trace elements such as LILE and LREE, with good internal mineral equilibrium for most trace elements. A few Louwrensia peridotites and one Hoedkop peridotite have garnets with sinusoidal REE patterns indicating strong depletion of all REE by extensive partial melting followed by re-enrichment of the middle REE. The most likely metasomatic agent(s) in Louwrensia and Rietfontein are kimberlitic melts. In the western NNP, Hoedkop and 
particularly Pofadder peridotites show greater garnet-cpx disequilibrium and greater fractionation between the REE, HFSE and LILE suggesting a possible role for volatile-rich metasomatic agents such as carbonatite or hydrous melts. The latter is also suggested by mineral reactions requiring infiltration of a K-bearing hydrous fluid into the Hoedkop peridotites. Pofadder peridotites show evidence for intense metasomatism characterised by extreme enrichment in incompatible trace elements (high LREE/HREE ratios). The striking resemblances in primitive mantle normalised trace element patterns between clinopyroxene from Pofadder peridotites and Cr-rich megacrysts studies (e.g., Janney \& Bell, abs. 4630, this volume) suggest that the Pofadder clinopyroxene may have crystallized directly from the magma parental to these megacrysts (presumably kimberlite).

\section{References}

Appleyard, C.M., Bell, D.R., and le Roex, a. P. (2007), Petrology and geochemistry of eclogite xenoliths from the Rietfontein kimberlite, Northern Cape, South Africa: Contributions to Mineralogy and Petrology 154(3):309-333

Bell, D.R., Schmitz, M.D., and Janney, P.E. (2003) Mesozoic thermal evolution of the southern African mantle lithosphere: Lithos 71(2-4):273-287

Boyd, F.R., Pearson, D.G., Hoal, K.O., Hoal, B.G., Nixon, P.H., Kingston, M.J., and Mertzman, S. a., 2004, Garnet lherzolites from Louwrensia, Namibia: bulk composition and P/T relations: Lithos 77(1-4):573-592

Brey, G.P., and Köhler, T. (1990) Geothermobarometry in four-phase lherzolites II. New thermobarometers, and practical assessment of existing thermobarometers: Journal of Petrology 31(6): $1353-1378$

Chevrot, S., and Zhao, L., 2007, Multiscale finite-frequency Rayleigh wave tomography of the Kaapvaal craton: Geophysical Journal International 169 (1), 201-215.

Davies, G. R., Spriggs, A. J. \& Nixon, P. H. (2001). A non-cognate origin for the Gibeon kimberlite megacryst suite, Namibia: Implications for the origin of Namibian Kimberlites. Journal of Petrology 42, 159-172.

Davis, G., Krogh, T. \& Erlank, A. J. (1976). The ages of zircons from kimberlites from South Africa. Carnegie Institution Yearbook 75, 821-824.

Franz, L., Brey, G.P., and Okrusch, M. (1996b) Steady state geotherm, thermal disturbances, and tectonic development of the lower lithosphere underneath the Gibeon Kimberlite Province, Namibia.: Contributions to Mineralogy and Petrology 126(1-2):181-198.

Griffin, W. L., Batumike, J. M., Greau, Y., Pearson, N. J., Shee, S. R. \& O'Reilly, S. Y. (2014). Emplacement ages and sources of kimberlites and related rocks in southern Africa: U-Pb ages and $\mathrm{Sr}-\mathrm{Nd}$ isotopes of groundmass perovskite. Contributions to Mineralogy and Petrology 168, 1032.

Janney, P.E., Shirey, S.B., Carlson, R.W., Pearson, D.G., Bell, D.R., Le Roex, a. P., Ishikawa, a., Nixon, P.H., and Boyd, F.R. (2010) Age, Composition and Thermal Characteristics of South African Off-Craton Mantle Lithosphere: Evidence for a Multi-Stage History: Journal of Petrology 51(9):1849-1890

Kobussen, A.F., Griffin, W.L., and O'Reilly, S.Y. (2009) Cretaceous thermo-chemical modification of the Kaapvaal cratonic lithosphere, South Africa: Lithos 112S:886-895

Kobussen, A.F., Griffin, W.L., O'Reilly, S.Y., and Shee, S.R., 2008, Ghosts of lithospheres past: Imaging an evolving lithospheric mantle in southern Africa: Geology, 36 (7)515-518

Luchs, T., Brey, G.P., Gerdes, a., and Höfer, H.E., (2013) The lithospheric mantle underneath the Gibeon Kimberlite field (Namibia): A mix of old and young components-Evidence from Lu-Hf and Sm-Nd isotope systematics: Precambrian Research 231:263-276

Mitchell, R.H. (1984) Garnet lherzolites from the Hanaus-I and Louwrensia kimberlites of Namibia.: Contributions to Mineralogy and Petrology 86(2):178-188.

Pearson, D.G., and Wittig, N. (2008), Review Formation of Archaean continental lithosphere and its diamonds : the root of the problem: Journal of the Geological Society London 165:895-914.

Pollack, H.N., and Chapman, D.S. (1977) On the regional variation of heat flow, geotherms and lithospheric thickness: Tectonophysics 38: 279-296.

Rudnick, R., and Nyblade, A. (1999) The thickness and heat production of Archean lithosphere: constraints from xenolith thermobarometry and surface heat flow: Mantle Petrology: Field Observations and High Pressure Experimentation: A Tribute to Francis R. (Joe) Boyd (6):3-12 